\title{
The Impact of Climate Change on Regional Government Expenditures: Evidence from Russia
}

\author{
Simo Leppänen ${ }^{1}$ - Laura Solanko ${ }^{2}$ - Riitta Kosonen ${ }^{1}$
}

Accepted: 7 October 2015 / Published online: 22 October 2015

(C) The Author(s) 2015. This article is published with open access at Springerlink.com

\begin{abstract}
This paper explores an almost untouched topic in the fast-growing climate econometrics literature - the implications of climate change for government expenditures. Using a rich sub-national dataset for Russia covering 1995-2009, we estimate the impacts of changes in climatic conditions through short-term variation and medium-term changes in average regional temperatures and precipitation. We show a strong and robust negative (but nonlinear) relation between regional budget expenditures and population-weighted temperature. The results indicate that an increase in temperature results in a decrease in public expenditures and that the magnitude of this effect diminishes the warmer the region. Further, our results suggest that the benefits from warming accumulate and that adaptation measures could help leverage those benefits. The estimated decreases in regional government expenditure are, however, quite small. In mild warming scenarios, according to our estimates Russia saves roughly USD 3-4 billion in regional government expenditures between 2000 and the 2020s without undertaking adaptation measures, depending on the scenario. It should be noted that our results are estimated for a scenario of mild temperature increase $\left(1-2{ }^{\circ} \mathrm{C}\right)$. Larger tem-
\end{abstract}

We thank Mika Kortelainen, Tuukka Saarimaa, Matti Liski, François Libois, Vincenzo Verardi and Veli-Pekka Tynkkynen for valuable comments. We are very grateful for The Academy of Finland for financing this study (Grant No 255635, headed by Prof. Riitta Kosonen from Aalto University, Center for Markets in Transition).

$\triangle$ Simo Leppänen

simo.leppanen@aalto.fi

Laura Solanko

laura.solanko@bof.fi

Riitta Kosonen

riitta.kosonen@aalto.fi

1 Center for Markets in Transition (CEMAT), Aalto University School of Business, Lapuankatu 2, 00100 Helsinki, Finland

2 The Bank of Finland Institute for Economies in Transition (BOFIT), Bank of Finland, P.O. Box 160, 00101 Helsinki, Finland 
perature increases are likely to have dramatic consequences e.g. from loss of permafrost and methane release that are impossible to predict with available historical data.

Keywords Climate change $\cdot$ Public expenditures $\cdot$ Adaptation $\cdot$ Non-linearity $\cdot$ Russia

JEL Classification Q54 · Q58 $\cdot \mathrm{H} 72 \cdot \mathrm{R} 59 \cdot \mathrm{C} 50 \cdot \mathrm{P} 20$

\section{Introduction}

There is a strong consensus that the earth is experiencing man-made climate change caused by such factors as accumulation of greenhouse gases in the atmosphere and black carbon deposition on land and sea surfaces. The recent report by the IPCC (2014) documents warming of the atmosphere and oceans, rising sea level, as well as the loss of snowpack and ice sheets. Climate change is likely to have major impacts on natural and human systems on all continents in coming years, eventually reflecting into countries' economies and consequently on their public finances. The academic discussion around fiscal impacts of these huge changes so far is largely policy-based and focused on two large topics: mitigation costs like emission taxes and direct budgetary effects of extreme weather events that are likely to become increasingly intense and frequent due to global warming (See Jones et al. 2012 for a survey).

Even modest and gradual climate disruption, however, may affect public finances through e.g. shifts in economic structures, weather-induced changes in public health, revised heating/cooling expenditures and adaptation costs related to public infrastructure. The research bias towards mitigation may arise from an assumption that adaptation is largely a private sector issue. For example, Tol (2005) argues that national governments and international organizations need not participate in climate change adaptation efforts due to the local nature of the problem.

On the other hand, governments, as providers of public goods and services and holders of broad powers, implicitly have a stake in adaptation as far as it impacts the ability of the government to function effectively and address market failures. Governmental adaptation costs may arise on many fronts, e.g. through public transport networks, developing public health responses or securing coastal areas. Notable uncertainties and imperfect information (e.g. in distinguishing weather variations from permanent climate shifts) could prevent efficient private-sector adaptation and response (Jones et al. 2012). Osberghaus and Reif (2010) discuss local externalities (e.g. overdrafts of groundwater from stepped up farm irrigation) and the production of local public goods (e.g. sea dikes) in response to climate change. Moreover, poor countries may lack private sector with adequate financial resources for adaptation due to financial market imperfections and other factors. Finally, governments may have to move ahead with adaptation measures even against some possible theoretically efficient allocation of responsibilities and costs, if political pressure from voters and interest groups becomes too compelling.

This study is an early step in filling the research gap in econometric analysis of public adaptation costs of climate change. By focusing on sub-national data for an enormous and climatically heterogeneous country, Russia, we highlight the effects caused by moderate changes in temperature and precipitation on regional government expenditure. We want to emphasize that our aim is not to achieve a complete picture of climate change impacts although temperature and precipitation are the key variables in climate change analysis and discussions. Instead, we use the two most widely used indicators (temperature and rainfall) to proxy for the 
magnitudes of climate change impacts as is often done in the climate econometrics literature (e.g. Schlenker and Roberts 2009). Thus, our results should be considered only to concern climate change with respect to changes in temperature and precipitation although we refer simply to climate change in our analysis for brevity.

Using annual data from 1995 to 2009 to analyse changes in regional government expenditure across 78 Russian regions, our estimations show a significant negative relation between temperature and expenditure per capita. Our main result is that temperature rise over the short term (a limited adaptation setting) reduces regional government expenditures in cold regions and that this effect attenuates in a non-linear manner the warmer the region. While the results become less trustworthy over a longer time horizon due to the scantiness of observations, we find evidence suggesting that weather benefits accumulate, i.e. warming tends to have a larger medium-term effect on decreasing regional government expenditures than in the short term. We also find some evidence that housing and communal expenditures are one mechanism through which climate and weather affect total expenditures. The benefits are fairly small although they might increase with proper adaptation. Under our mild warming scenario, Russia saves between just over USD 2 billion to USD 4 billion in regional government expenditures between 2000 and the 2020s without any adaptation measures. We find support to our results with the aggregate temperature variable from higher frequency degree days variables.

We believe Russia serves as a useful benchmark in quantifying potential fiscal effects of global changes in climate. It is the world's largest country in terms of land area and has a highly versatile climate that provides a good basis for empirical analysis. The public sector in Russia clearly also has a non-negligible effect on the economy with its regional government expenditures equalling almost $20 \%$ of GDP. Further, the average temperature in Russia has increased considerably faster than global temperature in recent decades, suggesting that warming of climate is truly happening there. If moderate, but persistent, climate change has any fiscal effects, Russia would be a natural candidate for a place where they would materialize. One needs to note, however, that this discussion only reflects regional government expenditure impacts in the case of mild climate change and reactive adaptation. Radical changes (e.g. partial melting of the permafrost, which covers roughly two-thirds of Russia) would have large, hard-to-quantify effects.

The paper is structured as follows. In Sect. 2, we elaborate our choice of Russia as an ideal setting for examining expenditure impacts of climate change. Section 3 discusses the existing literature. Section 4 outlines the methodological issues on estimating climate change effects and presents our estimation strategy. Section 5 describes our dataset and the variables used. The estimation results are presented and discussed in Sect. 6. Section 7 concludes.

\section{Russia as a Test Laboratory}

\subsection{Temperature Changes and Climate Policy in Russia}

Russia is an interesting subject for studying potential fiscal effects of climate change. First, the country's geographical size and versatile climatic conditions make it an ideal candidate for an empirical study of climate effects. Russia encompasses Arctic, sub-Arctic, moderate and subtropical climatic zones. The average annual temperatures differ by as much as $15{ }^{\circ} \mathrm{C}$ between the southwest and northeast corners of Russia (Kotlyakov 2002). The permafrost, as mentioned, covers roughly two-thirds of Russia's land area. 


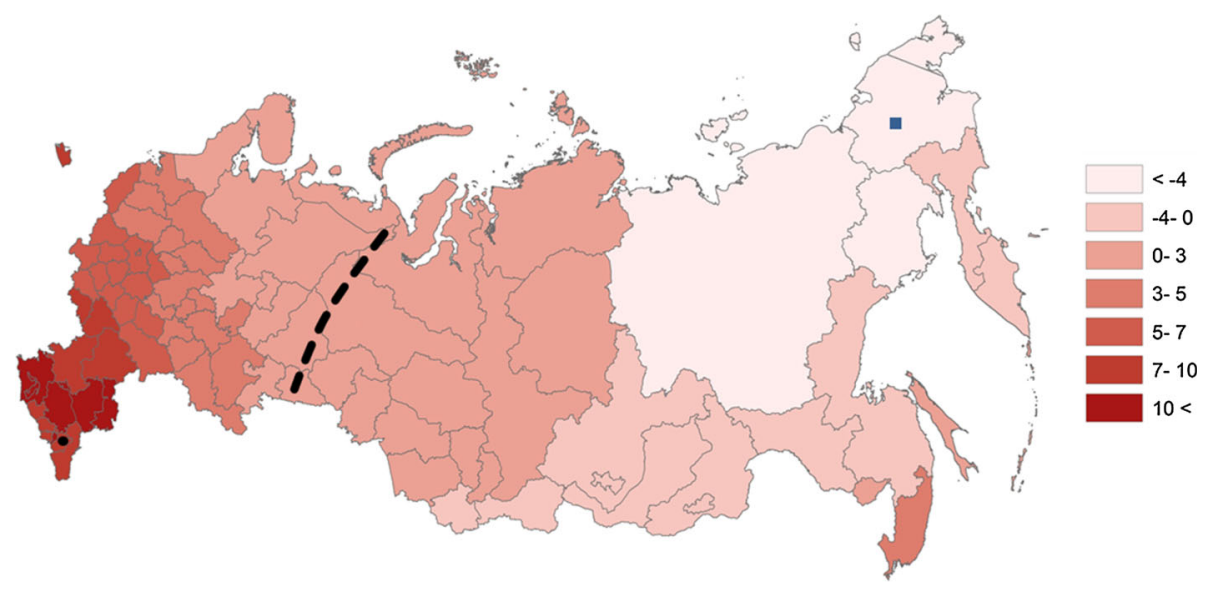

Fig. 1 Map of average annual temperatures (1995-2009) in Russian regions, $\left({ }^{\circ} \mathrm{C}\right)$. Temperatures coded at the regional level are based on administrative borders. The approximate location of the Ural Mountains is shown with the black dashed line. The two regions are excluded from our analysis: the Chukotka region (square) as an outlier and the Chechnya Republic (dot) due to the unreliability of available data. Source: meteo.ru database of weather stations, authors' calculations.

Figure 1 shows population-weighted temperature patterns among Russian regions based on our data (description in Sect. 5.2.). The general pattern of warm southern and western regions contrasts nicely with cold northern and far-eastern regions. This rich climatic variation also improves the identification properties of our climate data compared to climatically homogenous countries such as the UK or Japan.

Temperatures in Russia have been rising faster than the global average for several decades. Temperatures in the Arctic have been rising at almost double the global average. According to Russia's Federal Service for Hydrometeorology and Environmental Monitoring (Roshydromet 2008), the average annual temperature has increased by $1.29{ }^{\circ} \mathrm{C}$ during the last roughly one hundred years in Russia, while global warming for the same period was $0.74{ }^{\circ} \mathrm{C}$. Furthermore, average warming in Russia has apparently intensified in recent decades; it was $+1.33{ }^{\circ} \mathrm{C}$ for the period $1976-2006$ and the trend has continued. These trend differences are visible in Fig. 2, which shows the simple 10-year moving average of annual temperature deviations from the 1951-1980 average globally and in Russia from 1910 to 2014. Due to its extreme northern location, temperature increases have clearly been more drastic in Russia than globally since the 1980s.

The expected climate change impacts for Russia are versatile as evidenced in the impact assessment by Roshydromet (2014). For example, growing season for crops will become longer but at the same time some pests are expanding northward and eastward. Higher thermal comfort is expected in Russian north but the adverse health effects of heat waves will likely increase. Energy demand for heating will decrease due to shorter heating season but correspondingly the need for cooling in the warm season will increase. If climate change and global warming are likely to have had an effect on government finances somewhere, Russia is a natural candidate.

Second, Russia plays a key political role in climate change negotiations. The world's fourth largest $\mathrm{CO}_{2}$ emitter after China, the US and India (Turkowski 2012), Russia is also the largest national terrestrial carbon sink (Lioubimtseva 2010). Despite the strong evidence of climate warming and active involvement in international climate negotiations, however, Russia has 


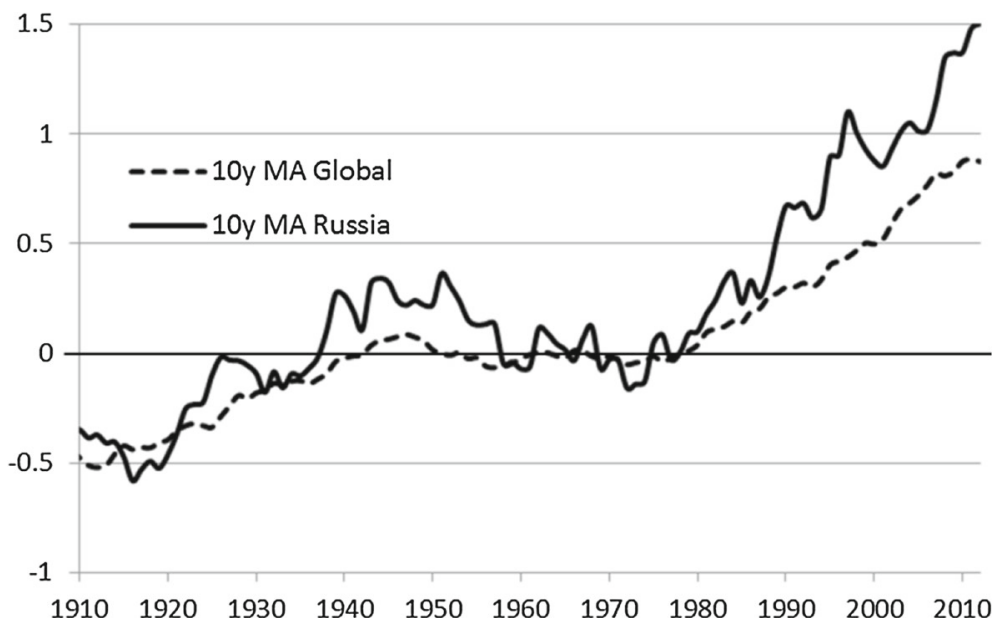

Fig. 2 Annual temperature deviations $\left({ }^{\circ} \mathrm{C}\right)$ compared to $1951-1980$ average; 10-year moving average for Russia and the world. Source: Calculated from Berkeley Earth data (2014)

been reluctant to commit to concrete greenhouse gas emission reductions. The reticence to get involved with climate change mitigation reflects several factors. Climate scenarios for Russia, a relatively cold and dry country, at least superficially imply beneficial trends like increasing average temperatures and precipitation. Russia also hopes to reap big economic benefits from climate change such as the "Northern Sea Route" (once the legendary Northeast Passage), as well as offshore drilling opportunities and high-latitude agriculture. As a result, many Russian scientists are convinced Russia is a net winner from climate change. Even the International Panel of Climate Change (2007) has noted the initially positive economic effects for the Russian economy.

With low enthusiasm for taking the lead in dealing with climate change, Russia, which is classified as a high-income country by the World Bank, prefers to align itself with developing economies. Further, the Russian public generally opposes the use of public funds on climate change mitigation (Korppoo 2008). Nevertheless, GAIN's (2012) climate change vulnerability ranking indicates Russia faces serious challenges from climate change, ranking it $39^{\text {th }}$ most susceptible out of some 180 countries surveyed. Moreover, any gains from climate change will be unevenly distributed across Russia's regions. Many regions face devastating consequences over the longer term. Like the rest of the world, climate change is likely to increase the frequency of extreme weather events. Forest and peat fires could increase, as well as flooding, land erosion and public health challenges (Korppoo 2008; Turkowski 2012). Near-surface thawing of the permafrost due to climate warming could be catastrophic for Russia's northern infrastructure, which is largely built on permafrost foundations (Pynnönniemi 2012). Furthermore, thawing of the permafrost could lead to huge increase in earth-based methane emissions that would exacerbate climate change dramatically (Lioubimtseva 2010).

At the time of writing Russia has opted out from international climate agreements, choosing instead to establish its own program. President Vladimir Putin signed a decree in September 2013 committing Russia to keep its greenhouse gas emissions at least $25 \%$ below the 1990 level by 2020. There are also other signs that Russia has increased interest in dealing with climate change. A presidential advisor on climate change has been appointed, new legislation enhancing energy efficiency and renewable energy usage has been accepted 
and Russia is planning its own carbon credit trading system. At the moment, Russia's targets could hardly be described as ambitious. Its 2011 carbon emission levels were roughly a third below the year 1990 baseline level. Furthermore, its outdated industrial base is highly energy inefficient and Russia's energy efficiency will automatically improve with almost any fixed capital investment. Thus, the current emission reduction goals will probably be met without any actual mitigation efforts. If Russia's greenhouse gas emissions were to increase at their recent pace, they would return to the 1990 level around 2025 (Lioubimtseva 2010; Turkowski 2012). The current economic recession has made it even easier to hit stated emission targets.

\subsection{Russia's Regional Public Finances}

Russia is quite heterogeneous in economic terms, which makes it an ideal candidate for fiscal decentralization. Institutionally, Russia is a federation consisting of the federal government and 80 subjects of federation, i.e. regional governments. Over roughly the past twenty years, the Russian Federation has travelled a long path from a unitary state, through extreme decentralization, to becoming a well-defined, highly centralized, federation. Broadly speaking, the past twenty years can be divided into two periods; haphazard and spontaneous fiscal and political decentralization in the 1990s and recentralization in the 2000s. The evolution of Russia's fiscal federalist arrangements (i.e. how fiscal rights and responsibilities are divided between levels of government) has been actively researched and documented in numerous studies including De Silva et al. (2009), Desai et al. (2003), Solanko and Tekoniemi (2005) and Zhuravskaya (2010). Four broad issues characterize Russian fiscal federalism.

First, the Russian regions are heterogeneous in almost every aspect of economic development. The differences in e.g. per capita income, in public health, wages, industrial structure and tax revenues are huge. In 2009, the fiscal capacity gap difference between the richest and the poorest region was 48 times (World Bank 2011). Over the last ten years, the federal fiscal transfers have become better formalized and focused. Thus, federal equalization transfers today iron out the largest inequalities, although a seven-fold gap in regional fiscal capacity still remains.

Second, formal revenue autonomy is negligible. Even in the 1990s, regional authorities had only limited powers to decide on tax bases or tax rates. Apart from the corporate income tax in the 1990s and the property tax in the 2000s, all tax rates and bases are centrally determined. Further, possibilities to finance budgets with sub-national debt are limited (Kurlianskaya 2013). Third, autonomy on the expenditure side is quite limited. Most social spending is implemented through regional budgets. These include outlays for health, education and housing that jointly constitute almost $70 \%$ of consolidated regional expenditures (Rosstat, Regioni Rossii). Most of all social expenditures are mandated in federal laws and regulations. Regions have somewhat more freedom in deciding on various benefits to regional (public and private) enterprises under the heading of "national economy." These expenditures constituted roughly $15 \%$ of regional expenditure in 2006-the midpoint of our time-series.

Fourth, minimal formal autonomy notwithstanding, Russian regions have considerable powers in implementation of federal and regional legislation. Despite fairly uniform rules and regulations on social expenditure items, actual outcomes differ widely (World Bank 2011). Over the past twenty years, regions have proven successful in influencing both tax bases and effective rates e.g. by affecting regional tax collection, tolerating tax arrears and giving preferential treatment through regional regulations (Slinko et al. 2005). 


\section{Literature Review}

While there are many mechanisms through which climate change adaptation costs might reflect on government expenditures ${ }^{1}$, the literature on fiscal costs and benefits of climate change is scarce. A typical limitation is that such studies must rely on assumptions about future adaptation behaviour. Among the few available studies, Osberghaus and Reif (2010) provide estimates for European countries with a methodology largely based on "guesstimates" of public sector involvement in adaptation investments. The World Bank (2010) estimates the cost of hard adaptation measures (i.e. those requiring engineering responses) in developing countries by analysing additional investment needs in various economic sectors. Both studies estimate the effects to be relatively low, although there are big differences, especially among the poorer countries. Bräuer et al. (2009) use a combination of qualitative-quantitative analysis of climate change impacts on several sectors to estimate the direct and indirect effects of climate change on government finances in Germany. They estimate that by 2100 the decrease in revenues and increase in government spending could result in a negative impact on the government expenditures equalling a GDP loss of 0.6-2.5\% compared to a reference scenario. For 2050, the results are less clear and might even have a slightly positive effect. These methods have utility, but the underlying behavioural assumptions are always open to criticism.

A relatively new, but rapidly growing, body of literature on fiscal effects of natural disasters complements adaptation literature through the use of historical data on past natural disasters. There is strong scientific consensus that climate change will increase the severity and occurrence of weather related disasters, and that such disasters have significant economic and fiscal repercussions. Ouattara and Strobl (2013) use data for Caribbean countries and find a positive government spending reaction persisting up to two years to large hurricanes. Schuknecht (1999) finds a significant negative effect of catastrophes on fiscal balances in a fixed effects setting with developing country data. Borensztein et al. (2008) find similar results. Based on EU and US case studies, Heipertz and Nickel (2008) conclude that the combined direct and indirect impact of extreme weather events on public finances was between $0.3-1.1 \%$ of GDP. Lis and Nickel (2009) estimate a panel data model of 138 countries, concluding that extreme weather events have a fiscal impact of $0.23-1.1 \%$ of GDP depending on the country group. Noy and Nualsri (2011) assert that developed countries exhibit counter-cyclical, and developing countries pro-cyclical, fiscal behaviours in the aftermath of natural disasters. Melecky and Raddatz (2011), using data of high- and middle-income countries for 1975-2008, find that government expenditure increases and budget deficits worsen after natural disasters.

These studies consistently indicate that extreme-weather-related phenomena affect public expenditures. What is missing is in the literature is evidence on how moderate, but persistent, changes in climate might affect public finances. This is precisely where we wish to make a contribution to the literature by offering an alternative way to estimate fiscal costs that is based on realized, historical data from a large, heterogeneous economy that has been experiencing warming.

The existing literature on determinants of public expenditure is deep and has its roots already in the political economy discussions of the late nineteenth century, but climaterelated variables are all but non-existent in the discussions. Broadly speaking, factors shaping public expenditure can be grouped into macroeconomic, demographic and institutional categories. The literature often argues that there is a positive relation between income levels and most expenditure categories and that government expenditures tend to increase in economic

1 Examples of such mechanisms are e.g. heating/cooling of government owned buildings, road maintenance, fighting forest fires, agricultural subsidies and health care. 
upturns, but adjust slowly in downturns (e.g. Shelton 2007). However, both results have been seriously challenged by e.g. Durevall and Henrekson (2011) who use long historical datasets from the UK and Sweden.

On the contrary, there is a broad consensus that the demographic structure of a country matters for the level and structure of its public expenditure. Population density tends to produce negative elasticities for defence, transport and communication and merit goods. Also, population density would seem to be positively linked with housing expenditures (Sanz and Velázques 2002). Age structure and dependency ratios affect public expenditures greatly (Sanz and Velázques 2002; Shelton 2007; Durevall and Henrekson 2011).

A country's political system and institutional arrangements bear on its public expenditures. Since most of the existing literature on public expenditure determinants uses cross-country data, the effects of the institutional differences are not easily analysed. However, a rich body of political economy literature considers institutional and political determinants of fiscal outcomes, mainly using regional datasets. In his seminal paper based on the US state government data, Merrifield (2000) argues that a whole range of political variables, including political fragmentation and turnover rates of state-level politicians, may greatly shape statelevel public finances. There is a rapidly growing body of literature taking advantage of the variation in Russia's regional institutions. To cite an example, a recent paper of Schultz and Libman (2015) finds that regional responses to the massive forest fires across Russia in the summer 2010 depended on characteristics of regional governors.

\section{Empirical Methodology}

\subsection{Estimation Through Annual Weather Variation and Mid-Term Climate Change}

Dell et al. (2014) note that the word climate is reserved in the literature for the distribution of weather outcomes (e.g. annual average temperature, precipitation sum, etc.) and can be summarized by weather averages over several decades, while the word weather describes a particular realization from the climate distribution and can vary notably in the short term. In this paper, we will use the same terminology and conceptual approach. There is one notable econometric problem in estimating climate impacts. This follows from the very definition of climate, which essentially makes it a fixed regional variable in an econometric sense. Thus, we cannot include a general regional fixed effect in a climate model (as it would be perfectly collinear with the climate variable) and a model without a regional fixed effect might suffer from omitted variable bias. This is most likely the case in Russia, where there is considerable heterogeneity among regions. We approach the problem of estimating climate with two distinct estimation strategies.

First, we will run a fixed-effects (FE) model:

$$
Y_{i t}=\alpha+\mu_{i}+\theta_{t}+f\left(X_{i t}\right)+g\left(P_{i t}\right)+\sum_{j}^{K} \gamma_{j} Z_{j i t}+\varepsilon_{i t}
$$

where $Y$ is regional expenditures in year $t$ in real terms, $X$ is annual temperature realization, $P$ similarly for precipitation, $Z_{j}$ the control variables, and $\mu_{i}$ and $\theta_{t}$ regional and time dummies. Regional fixed effects control for any unobserved region-specific time-invariant variables that may affect our dependent variable while the time dummy controls for country-wide trends (e.g. oil price changes). 
As we cannot estimate the climate effect directly in an FE model, the strategy is to identify the effects of climate change through annual variation in weather. Deschênes and Greenstone (2007) use a similar approach with an agricultural application. However, as Seo (2013) argues, the FE model fails to grasp potential adaptation due to its short-term aspect. Thus, the FE approach basically gives us the effect of climate change with very limited adaptation (that would be applicable within a year) and might be interpreted as a "no-adaptation" benchmark result. The intuition behind this strategy is that what would happen if the annual weather variation from the average regional weather (i.e. climate) in a particular year would become permanent.

To tackle jointly the adaptation and omitted variable problems, we employ our second estimation strategy, which, Dell et al. (2014) argue, comes closest to estimating medium-term impacts of climate change. Consider the model (presented along lines of Dell et al. 2014, where our time subscript is now $d$ indicating decade. Thus, $C_{i d}$ being the climate in period $d$ obtained through averaging annual weather (temperature and precipitation separately) figures and taking the first difference:

$$
Y_{i d}-Y_{i, d-i}=\beta\left(C_{i d}-C_{i, d-1}\right)+\sum_{j}^{K} \gamma_{j}\left(Z_{j i d}-Z_{j i, d-1}\right)+\left(\varepsilon_{i d}-\varepsilon_{i, d-1}\right) .
$$

Burke and Emerick (2013) use this long-difference (LD) model for climate related study for US agriculture, while Dell et al. (2012) apply it to economic growth analysis. Naturally, $d$ does not have to be a decade; it could be longer or shorter, just as long as it is long enough to capture local climate from annual weather variation. The climate variable $C_{i d}$ has to include enough variation for identification meaning that we need data from area where the climate has actually changed in a mid-term time horizon. Technically, the change does not need to be permanent; i.e. we only need sufficient variation in climate for identification and the needed time depends on the region in question. For US agriculture, Burke and Emerick (2013) used five-year periods of 1978-1982 and 1998-2002. For climate versus economic growth with country level global data Dell et al. (2012) use fifteen year averages of 1970-1985 and 19852000. Due to the limited data span available for Russia, we will use two non-overlapping periods of 1995-2001 and 2002-2009.

We acknowledge that weather averages of less than ten years probably cannot credibly depict local climate, which somewhat undermines the analysis. Despite of this shortcoming, we believe that the long-difference model can serve as a guideline for whether the short-term effects obtained from the FE model will increase or decrease in the longer term-especially taking into account that the Russian mean temperature has steadily increased during our time-series as evidenced in Fig. 2 above. $^{2}$

Dell et al. (2014) and Burke and Emerick (2013) discuss the various benefits of the long-difference model approach. In the mid- to long-term, climate change might induce adaptation in behaviour of economic agents (e.g. technology and policies), intensification of climate change effects (e.g. desertification) and general equilibrium effects (price and factor reallocation) that cannot be captured with an FE model. Long-difference models are not a panacea though. For example, if the two periods are too far apart, e.g. several decades, it

\footnotetext{
2 In our data, the average Russian temperature has risen by $0.4{ }^{\circ} \mathrm{C}$ between periods $1995-2001$ and $2002-$ 2009. This is in line with Roshydromet's (2014) latest estimates that show an average increase of $0.43{ }^{\circ} \mathrm{C}$ in Russia's surface temperature per decade over the period 1976-2012. It is also clearly higher than the global average rate of $0.166{ }^{\circ} \mathrm{C}$ per decade during the same period (Roshydromet 2014). A simple t-test from regional temperature data shows that temperature is higher in the latter period with very high significance $(\mathrm{t}$-value $=18.1)$. For precipitation, the change is less clear, showing an average increase of $8.4 \mathrm{~mm}$. Even so, we can conclude that it is larger than zero at the $5 \%$ significance level.
} 
may well be that the transmission mechanism between climate and economy has changed so much that it is not plausible to assume common regression coefficient for the two periods. Such setting could happen due to above-mentioned technological advancements used for adaptation. However, comparing LD model with other options such as hedonic models (e.g. Mendelsohn et al. 1994; Dell et al. 2014) Burke and Emerick (2013) argue for the superiority of the LD model as it removes omitted region fixed effects.

It is important to note that generally fixed effect estimations is preferred to first differences due to its better efficiency (Angrist and Pischke 2009). However, because FE tends to amplify the $R^{2}$ especially with small data sets and the deviations from the mean is algebraically the same as differencing when $T=2$ (Angrist and Pischke 2009) as in our case, we choose to use the LD model here to follow the earlier literature. As can be seen in Table 7 in the Appendix where we have used fixed effects, the results follow the ones in Table 3 obtained through differencing.

\subsection{Model Specification}

In climate-related applications, the issue of non-linearity of weather (especially temperature) often arises. Several health-related studies (e.g. Deschênes and Greenstone 2011) confirm the intuitive observation that extreme heat and cold have negative effects on human health, while an optimum lies somewhere in between. Schlenker and Roberts (2009) demonstrate similar results for agriculture. Due to heterogeneity of Russia's regions, it is quite possible that non-linearities exist concerning the temperature effect on expenditures. Non-linearities in climate-related studies are often captured by examining temperature bins (as in the two studies mentioned above). For the bin approach to work properly, however, the data need to be highly disaggregated at the regional level (e.g. US county-level data that provide enough observations for each bin). This is not possible with the Russian data. Thus, we test for non-linearities using both linear and quadratic specifications for the climate variables. This is the reason why the form of the temperature and precipitation variables is not explicitly specified in Eq. (1).

Climate and weather are ideal independent variables for econometric analysis. As Dell et al. (2014) note, weather shocks can be considered as random draws from the climate distribution and thus have strong causal identification properties. Despite the causal exogeneity of climate and weather, endogeneity problems can arise especially in a cross-sectional setting when we omit time-invariant variables that correlate with climate. Burke and Emerick (2013) argue that, like the FE model, the LD model has good identification properties concerning the climate variable. This is because climate trends (i.e. average weather over a longer period at various points of time) can also be interpreted as randomly assigned treatments to different regions.

Biased estimations could arise also in a fixed effects setting where there are time-varying omitted variables. To make sure we specify the model correctly, we therefore include several control variables. Dell et al. (2012) and Burke and Emerick (2013) rely only on region and time fixed-effect controls to avoid the so called over-controlling problem, which arises when we include control variables that are, in effect, the mechanism through which our variable of interest (climate) affects the dependent variable. To be prudent in including time-varying control variables, we therefore limit ourselves to variables already mentioned in the literature as important determinants of government expenditures.

In a setting where our statistical units (Russian regions) are geographically correlated, the error terms could be correlated as well and thereby violating the assumption of non-correlated error terms. While spatial autocorrelation leaves estimated coefficients unbiased, it can lead to incorrect standard errors undermining inference. This problem might arise in our case 
where neighbouring regions are correlated climatically in Russia. Because of this, we use Driscoll and Kraay (1998) standard errors in the FE model. These standard errors are robust to heteroskedasticity and general forms of spatial and temporal dependence (Hoechle 2007). For the LD model, we use typical heteroskedasticity robust standard errors because Driscoll and Kraay errors work poorly when the cross-sectional dimension of the data is much larger than the time dimension ( $i=78$ and $t=2$ in our long-difference setting).

Another issue to resolve is whether to include the lagged variables in the FE estimations. As Dell et al. (2014) note, inclusion of lags of the dependent variables as explanatory variables creates bias in panel models with short time periods. Thus, this is a potential problem with our relatively short panel of $T=15$ (1995-2009). In addition to shortness of our time dimension, there is no certainty on the underlying data generation process for the expenditure variables and lag of $y$ is not typically introduced into estimation in the econometric climate literature. For these reasons, we leave it out of our analysis as well. Concerning lags of the independent variables, the situation changes. There is no clear theory for the proper time dimension in which expenditure variables could react to weather. Thus, we test the best fit of weather variables and find that expenditures seem to have the most robust fit with the first lag of the temperature variable. This is reasonable taking into consideration that effects can easily be reflected into the expenditures with a lag due to budget planning and sequencing. In the LD model, lags are not relevant because we are looking at a change in the mid-term climate defined as annual averages over 1995-2001 compared to 2002-2009.

\section{Data and Variables}

\subsection{Dependent Variable}

Our main dependent variable is total regional government expenditures per capita as reported by Russia's Ministry of Finance and Federal State Statistical Service (Rosstat). Additionally, to detect the potential mechanisms through which weather or climate can affect expenditures, we run the analysis separately for per capita housing and communal expenditures (shortened as housing expenditures in the following analysis). This is among the few regional budget classes that are comparable and available throughout the 1995-2009 period in Russia. Although data-wise we cannot separate housing and communal expenditures from each other, housing expenditures at least provide an intuitive transmission mechanism from climate to expenditures (i.e. in a cold climate, higher temperature means lower heating costs). Roshydromet (2014) estimates that energy demand for heating will reduce notably but at the same time energy demand for cooling will increase in the warm season. According to Solanko (2006), heating is perceived as a semi-public good in Russia due to the heavy historical reliance on district heating typically provided by municipal heat and power plants. Furthermore, Rosstat figures show that in 2009 still roughly one-sixth of the housing stock in Russia was under state or municipal ownership (in 2000 roughly a third), with ownership shares ranging regionally from 2.5 to $35 \%$. Public ownership of housing is much higher in colder regions, and indeed the correlation between average temperature and share of public ownership in our data is -0.44 . This suggests housing as a potential channel for impacts of temperature changes on regional budget expenditures.

Our dependent variables are recorded in annual rubles terms, so Russia's high and volatile inflation rate has to be properly taken into account. To do this, we deflate regional expenditure figures with regional consumer price indices (cpi). As a robustness check, we also deflate expenditures using the annual price of the regional consumption basket (i.e. basically a 
purchasing power parity approach). To save space, we report here only the results from the cpi approach; they are easier to interpret and the results from the consumption basket specification are highly similar (available on request). Actual expenditure-per-capita variables are introduced in log form. Thus, the interpretation of the continuous variables' estimation coefficients is $\beta$ times $100 \%$.

Our dataset comprises annual regional level data across Russian regions for 1995-2009. We exclude Chechnya from the sample due to data unreliability and the Chukotka region due to its political peculiarities. ${ }^{3}$ Chukotka, with a population of 50,000 people, clearly has the lowest population density of all Russian regions (average population density in Russia is over 2000 times that of Chukotka) and it is the second coldest region in Russia. This leaves us with 78 regions in our final sample. Descriptive statistics of all independent and dependent variables are presented in Table 1.

\subsection{Regional Climate Data}

Our climate data are obtained from the online database of the All-Russian Research Institute of Hydro-meteorological Information (meteo.ru), which is funded by Roshydromet. The database provides daily and monthly temperature and precipitation data over several decades for more than five hundred weather stations located across the Russian Federation. For our estimations, we calculate the annual average temperature and sum of precipitation for the years 1995-2009 for 78 Russian regions in our main specification. Climate variable specification is highly context dependent. In agricultural studies, it is common to use "growing degree days" within certain temperature thresholds during the growing season. This approach tries to capture the biological relation between weather and vegetation growth. In some applications, seasonality may also matter (e.g. tourism). Because there is no clear intuition on seasonality or potential opposite effects concerning budget expenditures, we use annual temperature figures in our main specification. This also makes it easier to interpret the results in the framework of climate predictions.

However, for robustness check we construct higher frequency climate variables reflecting potential impacts through agriculture and energy use from heating and cooling. These variables are growing degree days (GDD) as described above as well as heating and cooling degree days (HDD and CDD, respectively). GDD variable is calculated as the sum of daily average temperatures between 8 and $32^{\circ} \mathrm{C}$ and truncated to $32^{\circ} \mathrm{C}$ during the growing season of April to August (similarly to Deschênes and Greenstone 2007; Guiteras 2009). HDD and CDD on the other hand are calculated as annual sum of daily average outdoor temperature differences to indoor comfort temperature of $18.3^{\circ} \mathrm{C}\left(65^{\circ} \mathrm{F}\right)$ following EPA (2014). For example, if outdoor temperature is $10^{\circ} \mathrm{C}$ we have a HDD of $8.3^{\circ} \mathrm{C}$ for the particular day and in similar fashion for outdoor temperature of $23.3{ }^{\circ} \mathrm{C}$ we get a CDD of $5{ }^{\circ} \mathrm{C}$. Our quadratic model take into account potential non-linearities concerning HDD and CDD, which according to Dell et al. (2014) is important as extreme temperatures provoke much stronger energy demand increases.

The weather data is calculated from the weather stations located within each region. Typically, a region has several weather stations, so the weather data are averaged from these stations to get a regional figure. For the large northern and eastern regions, we included only weather stations situated relatively close to regional capitals. We also exclude weather stations situated at very high altitudes. On average, we use data from 3.5 stations per region to calculate the annual regional temperature and precipitation variables of our estimations.

\footnotetext{
3 One of the wealthiest men in Russia, Roman Abramovich, served as governor of Chukotka from 2000 to 2008. During his period in office, regional revenues skyrocketed as part of the governor's personal wealth was taxed in the region.
} 


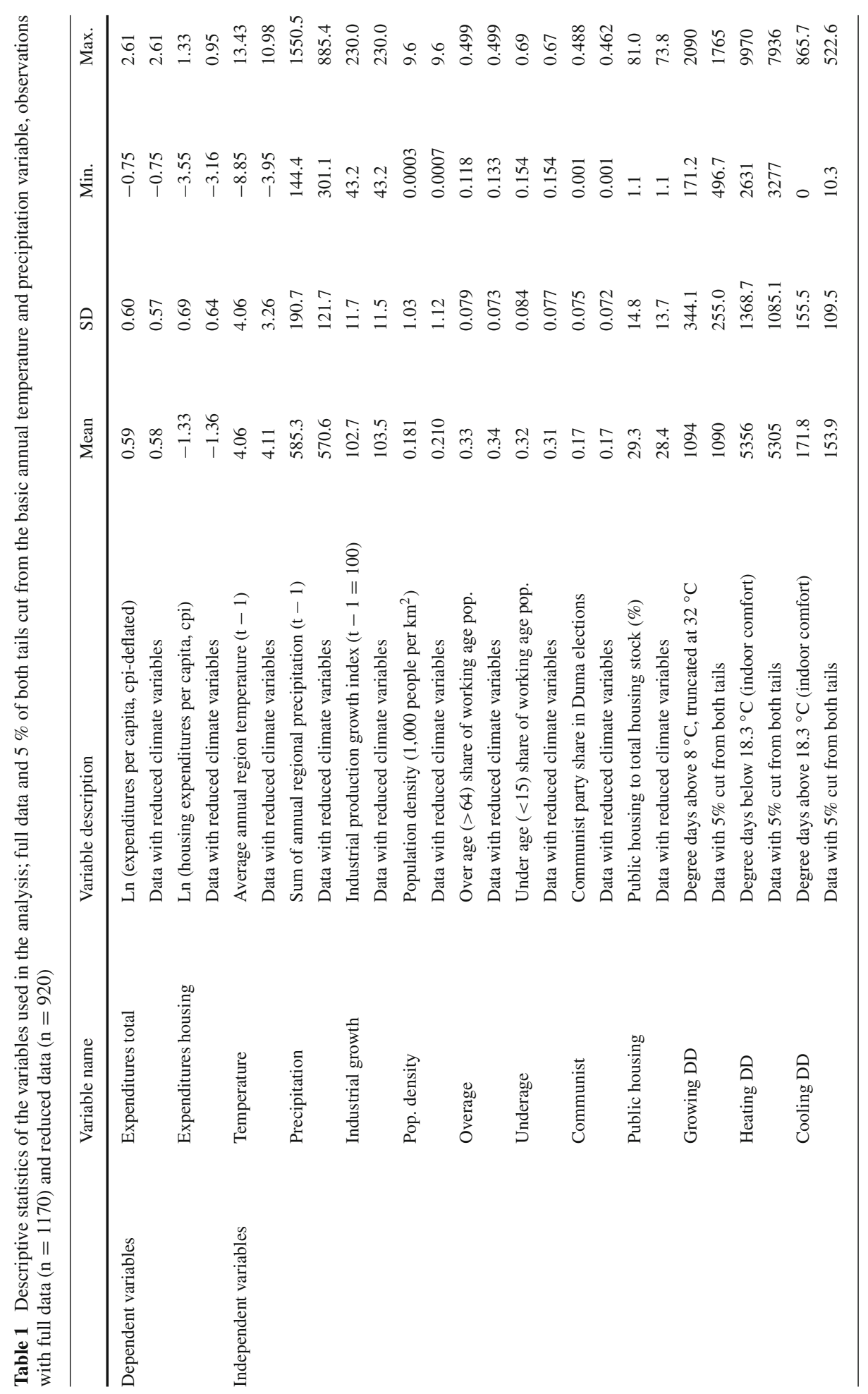


Our data-generating approach creates an upward bias in temperature data with respect to pure geographic dimensions, as the weights of large and cold northern and eastern regions in the weather data are reduced. However, as discussed in Dell et al. (2014), there are various criteria for aggregating weather data. In economic applications, the main options are spatialand population-weighted aggregation and should be selected depending on context. Spatial weighting is more appropriate for e.g. agricultural studies, while topics related to human activity are likely best captured by population-weighted weather data. Our data generation approach can be considered as largely population-weighted (due to weather station selection), but still allows a bit more weight for geographical size than a pure population-weighted aggregation. For robustness, we also run the regressions with data where $5 \%$ of observations are removed from both tails of the temperature and precipitation variables. This diminishes the role of potential weather outlier regions.

\subsection{Control Variables}

Our control variables were selected to represent the three categories of variables (macro, demographic and institutional), which, as discussed in Sect. 3, have been found important in the literature on determinants of public expenditure. We performed a robustness check on covariate selection in each regression by altering the included control variables (not reported here to save space). For the FE model, both the significance and coefficients of the weather variables were highly robust and quite strongly robust for the long-difference estimation.

To control for regional business cycles that could have notable effects on budget, we introduce regional industrial growth rate (Industrial_growth) as a covariate. Following Sanz and Velázques (2002), we include separate dependency ratios (dependents to working-age population) for younger and older population (Underage and Overage, respectively). We also control for regional population density (Pop_density). In the housing expenditure estimations we include the share of public houses in total regional housing stock (Public_housing). The source for these variables is Rosstat's Regioni Rossii publications.

Variables reflecting regional political and institutional circumstances are always hard to come by. Such variables are particularly scarce for Russia at the regional level, especially those that would consistently cover the full period 1995-2009. We chose here the regional share of the Communist Party vote (Communist) in elections of the Duma (Russia's lower house of parliament) as a proxy for regional political activism. ${ }^{4}$ This is a fairly straightforward measure of regional political dimensions and the Communist Party is the only party that has held a significant number of seats in the Duma throughout Russia's transition. This measure can also be considered as a proxy for regional antipathy towards the ruling party. The data was retrieved from the website of the Central Election Commission of the Russian Federation.

\section{Estimation Results}

\subsection{Short-Term Analysis Results}

We next present the results for our fixed-effects models for both total and housing expenditures. As will be shown, it appears that a typical linear model fails to sufficiently grasp the

\footnotetext{
4 Duma elections after the dissolution of the Soviet Union were held in 1993, 1995, 1999, 2003, 2007 and 2011. For our variable of the Communist Party's vote share, we calculate the data for the election intervals by linear combinations of voting share in the elections at time $t$ and $(t-1)$. This would approximate the development of the political sphere between elections. For reasons of data availability, we use the election data from 1993 instead of 1995.
} 
relation between weather and expenditures although the nationwide non-linear estimate is relatively similar. We will present the linear results as a reference point to the methodologies used in other climate econometrics literature. The results of the fixed effect estimates for both total and housing expenditures are shown in Table 2. The table presents results for both linear and quadratic models for total and housing expenditures with full data, as well as for robustness check with data where $5 \%$ from both tails of the temperature and precipitation variables are removed.

For total expenditures, our basic linear model (1) suggests that a rise in the annual (lagged) temperature decreases regional expenditures, i.e. a $1{ }^{\circ} \mathrm{C}$ increase leads to a roughly $3 \%$ decrease in regional expenditures per capita. No such significant relation seems to exist for precipitation. Underage and Overage are positively associated with expenditures, which is intuitive in the sense that education and healthcare are mostly sub-national responsibilities in Russia. Industrial growth also shows a significant positive relation and a larger role of the Communist Party would seem to be reflected as smaller expenditures. The causality of the Communist variable is unclear, however. It is possible that the Communist Party enjoys greater support in poor regions that lack money for public services. Indeed, there is a strong negative correlation $(-0.58)$ between regional income per capita and support of the Communist Party in the data. In the basic model for housing expenditures (5), the control variable results seem similar with the difference that Population density is now highly significant while Underage is not. However, there would seem to be no significant temperature or precipitation effect.

In the linear estimations, where the tails are cut for climate variables (models 3 and 7), our control variables seem fairly robust, while climate variables are insignificant. However, the linear model appears to lack sufficient flexibility to capture the effect of the climate variables. A quadratic relation seems to fit for temperature effect on total expenditures and is even more robust when tails are removed. There is also evidence in the cut tails regression (4) that precipitation has a similar (although less robust) non-linear effect.

To get a better sense of the non-linear climate relation, we build a graph where we show the temperature effects on total expenditures at different regional temperature levels based on the results in Table 2. In Fig. 3, the y-axis shows how many per cent expenditures would drop for a temperature increase of $1^{\circ} \mathrm{C}$ in regions with particular average temperature. The quadratic specification suggests that increase in temperature has a steep negative impact on expenditures in colder regions, while the effect approaches zero in warmer regions. In our full data results, the impact remains negative for even the hottest regions (but reverses at an annual average temperature of around $12^{\circ} \mathrm{C}$ ), while the cut data show additional warming starts to raise expenditures in those regions where average temperature is around $8{ }^{\circ} \mathrm{C}$ or higher. This supports the intuitive hypothesis that cold regions benefit from warmer weather, while the benefits diminish in warmer regions (and could even reverse for the hottest regions). We find some support for such U-shape effect for housing expenditures in the cut data (see Table 2 model (8), not graphed) suggesting that savings in housing expenditures due to warming become net costs already at around an average regional temperature of $4{ }^{\circ} \mathrm{C}$, which is roughly the Russian average temperature in our data.

To obtain a rough nationwide effect, we calculate a population-weighted average effect of regional effects. For total expenditures, we get a nationwide coefficient of -0.026 (i.e. 2.6 $\%$ decline per one degree increase) with full data and -0.015 with cut data. Thus, the nonlinear analysis confirms the decreasing impact of warming on expenditures, while the effect is clearly smaller. This suggests that non-linearities are helpful in understanding regional differences in climate impacts. As these might be important for policymaking, they should not be sidestepped. 


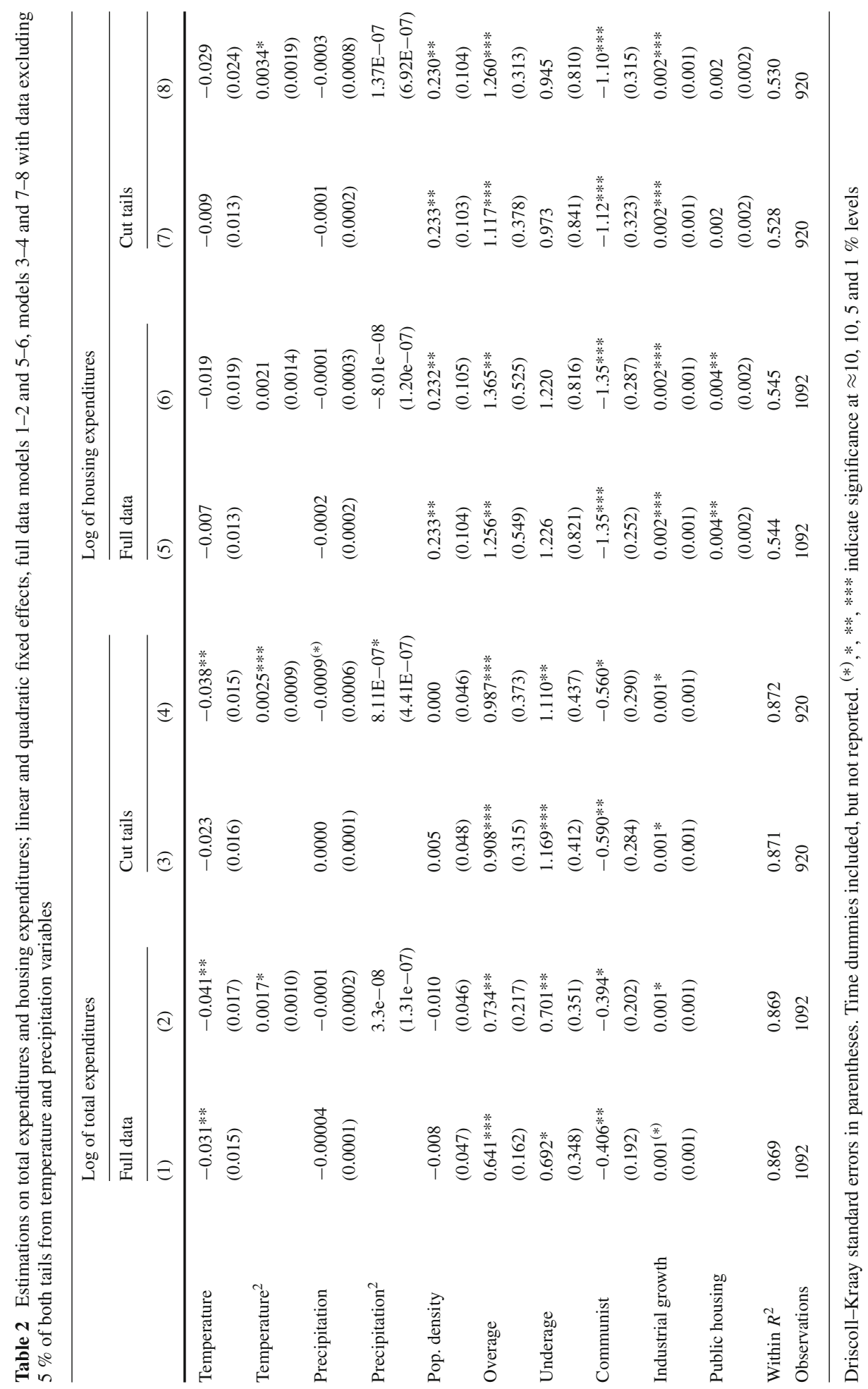




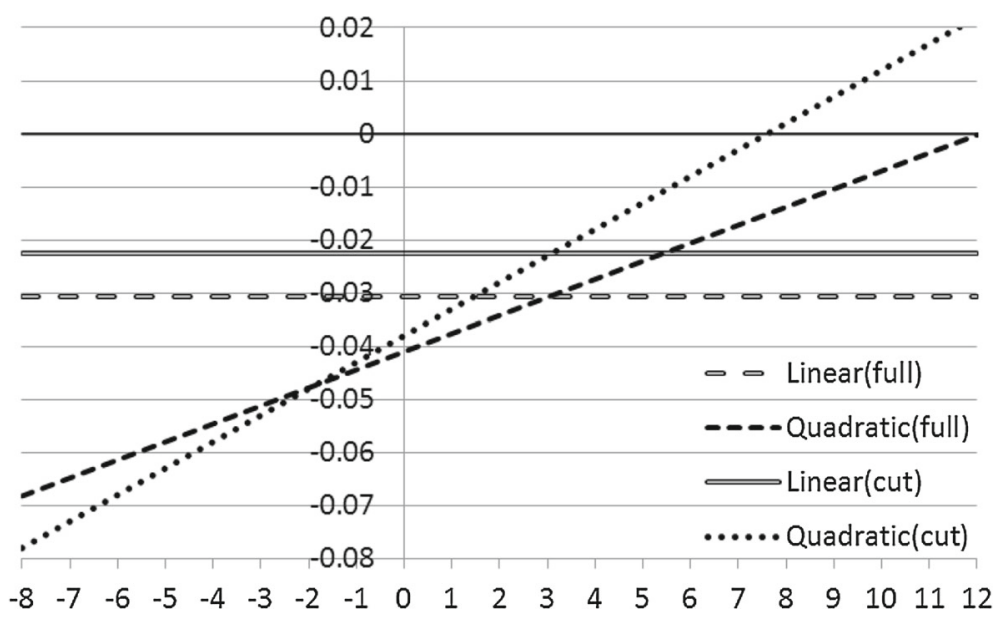

Fig. 3 Linear and quadratic fit for weather variation at different temperatures ( $\mathrm{x}$-axis is annual average temperature of a region in ${ }^{\circ} \mathrm{C}, \mathrm{y}$-axis is the temperature effect at different temperatures, $100^{*} \beta=\%$ )

\subsection{Longer-Run Effects}

We next address the question of adaptation through the LD model (Eq. 2), as well as the results with respect to climate scenarios. As noted in Sect. 4, the FE model only captures short-term adaptation (within a year). Thus, its ability to estimate longer-run climate impacts including adaptation is weak. In Table 3, we present our estimates for the LD model, which should better account for adaptation and/or potential intensification effects than the FE model. However, it should be emphasized that the long-difference results should be treated with great caution and taken mainly as indicating direction as to whether the benchmark effects of the FE model are likely to increase or decrease over the longer term. This is due to the small amount of available observations and relatively short time span for weather averages in our data. We do not find any significant non-linear impacts with the LD model and thus present only the linear model.

The results of Table 3 suggest that temperature has a cumulative effect on total expenditures; the longer-run coefficient is ten times larger in the absolute sense than the short-term FE estimate. The estimation suggests that $\mathrm{a}+1^{\circ} \mathrm{C}$ increase in regional average temperature leads to a decrease of roughly a third in real expenditures per capita. This magnitude seems implausibly high and we have to take into account that both expenditures and temperature differences in our data consists of solely positive values - due to economic development and general warming of the whole country-with the exception of two regions with temperature change of $-0.01^{\circ} \mathrm{C}$. Thus, the LD model effectively captures the fact that in regions of greater temperature increase, expenditures have increased less. Also, there might be some trend or non-fixed variable that we are unable to control for in the LD model. Nevertheless, it would seem that the temperature effect suggested by the FE model is probably larger when adaptation and intensification come into play. While temperature is significant and precipitation is not in the case of total expenditures, the situation is reversed for housing expenditures.

\subsection{Robustness Check with Alternative Temperature Variables}

Our results for the three degree day variables, working as a robustness check, are presented in Tables 5 and 6 in the Appendix. The tables replicate the models of Tables 2 and 3 but we have left out the control variables in the table to save space as they were robust to the 
Table 3 Long-difference (LD) estimations with full data and data excluding $5 \%$ of both tails from temperature and precipitation variables
Robust standard errors in parentheses

\begin{tabular}{|c|c|c|c|c|}
\hline & \multicolumn{2}{|c|}{ Total expenditures } & \multicolumn{2}{|c|}{ Housing expenditures } \\
\hline & Full data & Cut tails & Full data & Cut tails \\
\hline Temperature & $\begin{array}{l}-0.342 * * * \\
(0.122)\end{array}$ & $\begin{array}{l}-0.321 * * \\
(0.140)\end{array}$ & $\begin{array}{l}-0.228 \\
(0.182)\end{array}$ & $\begin{array}{l}-0.216 \\
(0.199)\end{array}$ \\
\hline Precipitation & $\begin{array}{l}-0.001 \\
(0.001)\end{array}$ & $\begin{array}{l}-0.001 \\
(0.001)\end{array}$ & $\begin{array}{l}-0.002^{(*)} \\
(0.001)\end{array}$ & $\begin{array}{l}-0.003 * * \\
(0.001)\end{array}$ \\
\hline Pop. density & $\begin{array}{l}-0.051 \\
(0.038)\end{array}$ & $\begin{array}{l}-0.046 \\
(0.042)\end{array}$ & $\begin{array}{l}0.227 * * * \\
(0.081)\end{array}$ & $\begin{array}{l}0.197 * * \\
(0.090)\end{array}$ \\
\hline Overage & $\begin{array}{l}0.265 \\
(0.922)\end{array}$ & $\begin{array}{l}0.517 \\
(0.997)\end{array}$ & $\begin{array}{l}2.385^{*} \\
(1.349)\end{array}$ & $\begin{array}{l}2.509 * \\
(1.439)\end{array}$ \\
\hline Underage & $\begin{array}{l}2.007 \\
(1.360)\end{array}$ & $\begin{array}{l}2.033 \\
(1.381)\end{array}$ & $\begin{array}{l}3.774 * * \\
(1.719)\end{array}$ & $\begin{array}{l}3.368 * * \\
(1.669)\end{array}$ \\
\hline Communist & $\begin{array}{l}0.323 \\
(0.450)\end{array}$ & $\begin{array}{l}0.442 \\
(0.653)\end{array}$ & $\begin{array}{l}-1.374 \\
(0.910)\end{array}$ & $\begin{array}{l}-0.383 \\
(1.263)\end{array}$ \\
\hline Industrial growth & $\begin{array}{l}0.017 * * * \\
(0.003)\end{array}$ & $\begin{array}{l}0.018^{* * * *} \\
(0.004)\end{array}$ & $\begin{array}{l}0.010 \\
(0.008)\end{array}$ & $\begin{array}{l}0.015^{* *} \\
(0.008)\end{array}$ \\
\hline Public housing & & & $\begin{array}{l}0.004 \\
(0.008)\end{array}$ & $\begin{array}{l}0.006 \\
(0.008)\end{array}$ \\
\hline$R^{2}$ & 0.30 & 0.30 & 0.19 & 0.21 \\
\hline Observations & 78 & 68 & 78 & 68 \\
\hline
\end{tabular}

new temperature variables. As can be seen, we do not find evidence on temperature effects through agriculture as the GDD variable is insignificant in both linear and quadratic models and in short and longer-run analysis. This could be due to relatively small role of regional governments in supporting Russia's agricultural sector. For example, in 2004 regional budget expenses to the agricultural sector in Russia were roughly 1.6 bln. USD (less than $2 \%$ of all budget expenses). On the other hand, HDD would seem to support the results of our main specification. As presented graphically in Fig. 4 of Appendix regions that have low HDD (i.e. warm regions) face decreasing expenditures if the HDD increases (i.e. temperature goes lower). Intuition behind this result is that in the warmest regions the expenditure drop due to colder weather in general is larger than possible increase for required additional heating. Conversely, for cold regions that have already high heating needs, further increase in HDD accrues increasingly high expenditures. The HDD estimations are very consistent with our main specification also in the sense that LD estimate is roughly ten times larger the FE estimate. We can find similarly intuitive results for CDD and housing expenses as in the case of HDD but these results are clearly less robust. This could be a result from Russia being generally a cold country and thus not needing much of air conditioning and also Russia is still relatively poor, especially its warmest regions, and thus might not have a high coverage of air conditioning.

\subsection{Warming Effect in the Framework of Climate Scenarios}

Finally, the use of simplistic proxies (temperature and precipitation) to describe climate change allows us to discuss our results in the context of climate change scenarios. Utilizing the GAEZ database (http://gaez.fao.org), which takes climate data from the Climate Research Unit of East Anglia (CRU-A, -B, -C and -D), we retrieve two climate-change predictions from the database to obtain the change in average temperature from 1995-1999 to 2020s. These predictions are simulated with the commonly used HadCM3 climate prediction model for 
Table 4 Climate scenarios for Russia and non-discounted change in Russia's regional government expenditures in two climate scenarios for the 2020 s

\begin{tabular}{|c|c|c|c|c|}
\hline \multirow[t]{3}{*}{ CRU climate scenarios } & \multicolumn{4}{|l|}{$2020 \mathrm{~s}$} \\
\hline & \multicolumn{2}{|c|}{ Full data } & \multicolumn{2}{|c|}{ Cut data } \\
\hline & $B 1$ & $A 2$ & $B 1$ & $A 2$ \\
\hline Temperature change for all of Russia $\left({ }^{\circ} \mathrm{C}\right)$ & 1.2 & 1.1 & 1.2 & 1.1 \\
\hline $\begin{array}{l}\text { Population-weighted total expenditure change suggested by the } \\
\text { non-linear FE models ( } 2 \text { and } 4 \text { in Table } 2 \text { ) in real terms (\%) }\end{array}$ & -3.1 & -2.7 & -1.8 & -1.6 \\
\hline $\begin{array}{l}\text { Non-discounted monetary impact in } 2013 \text { prices, USD billion (change } \\
\text { in } 2000 \text { expenditures by } 2020 \mathrm{~s} \text { ) }\end{array}$ & 3.9 & 3.4 & 2.3 & 2.0 \\
\hline
\end{tabular}

The reference point is average temperature for 1995-1999

the scenarios A2 and B1. ${ }^{5,6}$ Naturally, there is no objective reason to rely on these particular scenarios. However, our intention is to merely illustrate our results in a framework of actual climate predictions and these scenarios are regularly used in relevant discussions (e.g. the World Bank's climate change portal) and full presentation of prediction uncertainties would not serve the purpose of the paper. Although the scenarios initially provide quite similar climate predictions for Russia as a whole (before starting to deviate in decades further out), certain regional differences are apparent, so we present both for robustness. Due to relatively weak robustness of our precipitation estimates and higher uncertainty of the precipitation predictions we will focus here on temperature change scenarios.

We provide estimates only up to the 2020s (i.e. the average of 2011-2040 reference point given by the climate scenarios), because temperatures are expected to continue to further increase $\left(>2{ }^{\circ} \mathrm{C}\right)$, i.e. the benefits from warming become increasingly uncertain. Moreover, it is problematic to derive predictions outside the variation available in our data. From the scenarios, we calculated regional temperature predictions and multiplied these with the regional temperature gradients (i.e. derivate of the obtained quadratic function) to get regional impact estimates. We calculated a population-weighted average of the regional impacts to get an estimate for whole Russia.

To get some insight into the monetary impacts, we take Russia's regional government expenditures in year 2000 (roughly 1 trillion rubles). Inflating this figure using the consumer price index gives roughly 4 trillion rubles in 2013 prices, or USD 125 billion using the average RUB/USD exchange rate for 2013. The results are summarized in Table 4. In the B1 scenario, Russian regional governments save between just over USD 2 billion to USD 4 billion (in real terms, non-discounted), depending on the data set, between 2000 and the 2020 s due to warming. In the A2 scenario, the savings from milder temperatures ranges between USD 2 billion to roughly USD 3.5 billion over the period. Compared to, say, Russia's consolidated regional budget expenditures of USD 275 billion in 2013, the benefits are quite small. Barring any major uncertainties in the mid-scenario climate comparison, our weather data suggests that roughly half of the predicted $1.1-1.2{ }^{\circ} \mathrm{C}$ increase in annual mean temperature had taken place by the end of the 2000 s i.e. half of the expenditure benefits had already accrued.

\footnotetext{
5 http://www.metoffice.gov.uk/research/modelling-systems/unified-model/climate-models/hadcm3.

6 B1: low population growth, high GDP growth, low energy use, high land use changes, low resource (mainly oil and gas) availability, medium pace and direction of technological change favouring efficiency and dematerialization. A2: high population growth, medium GDP growth, high energy use, medium-high land use changes, low resource mainly oil and gas) availability, slow pace and direction of technological change favouring regional economic development.
} 
An intriguing question is whether these results are applicable in a global perspective. Russia offers a wide spectrum of temperature zones. This improves generality of the results compared to climatically homogenous countries like Japan or the UK. On the other hand, Russia is a cold country compared to most. The population-weighted mean annual temperature for Russia based on our data is around $4-5{ }^{\circ} \mathrm{C}$, leaving it with a small number of peers such as the Nordic countries and Canada (as presented in Dell et al. 2012). The fact that our results suggest a diminishing convex-shaped effect of warming on expenditures in such a cold country as Russia would indicate that similar benefits are probably not available in warmer countries. However, our longer-term results suggest that, with proper adaptation and potential intensification effects, the benefits could well be larger for Russia than the short-term analysis indicates.

\section{Conclusions}

In this paper, we examined the effect of climate change (concerning temperature and precipitation) on regional government expenditures using a rich regional-level dataset. This effect was estimated through short-term variation and mid-term change in average temperature and precipitation. The former approach conceptually gives us a no-adaptation benchmark effect while the latter approach captures potential adaptation better, but is less reliable due to the scantiness of observations and data variation.

Our short-term approach suggests that a rise in temperature reduces regional public expenditures in cold regions, becomes negligible in warmer regions and reverses in the hottest regions. Thus, the effect is non-linear. We find similar relation for precipitation but the result is not very robust. We also find some evidence that housing and communal expenditures provide a mechanism through which temperature affects total expenditures. We found support for the temperature effect result from estimations with higher frequency data using degree day variables.

Our non-linear and population-weighted estimate for the Russia-wide impact of a $1{ }^{\circ} \mathrm{C}$ increase in annual temperature is a decrease of $2.6 \%$ in regional budget expenditures in real terms. To estimate the monetary impact of warming we limited the duration of our climate scenarios up to 2020 s, when the expected warming still only slightly exceeds $1{ }^{\circ} \mathrm{C}$. Our estimates indicate that warming effects save the Russian regional governments somewhere over USD 2 billion to USD 4 billion, depending on the climate scenario, in expenditures in non-discounted US dollars between 2000 and the 2020s. Roughly half of these savings had already accrued by the end of the 2000s. Our mid-term model suggests that these benefits could well be larger when adaptation and intensification effects come into play. However, the mid-term result is less robust and our results cannot account for a large increase in temperature, which would likely have a dramatic effect through e.g. thawing of the permafrost that covers roughly two-thirds of Russia's land area.

Open Access This article is distributed under the terms of the Creative Commons Attribution 4.0 International License (http://creativecommons.org/licenses/by/4.0/), which permits unrestricted use, distribution, and reproduction in any medium, provided you give appropriate credit to the original author(s) and the source, provide a link to the Creative Commons license, and indicate if changes were made.

\section{Appendix}

See Tables 5, 6, 7 and Fig 4. 


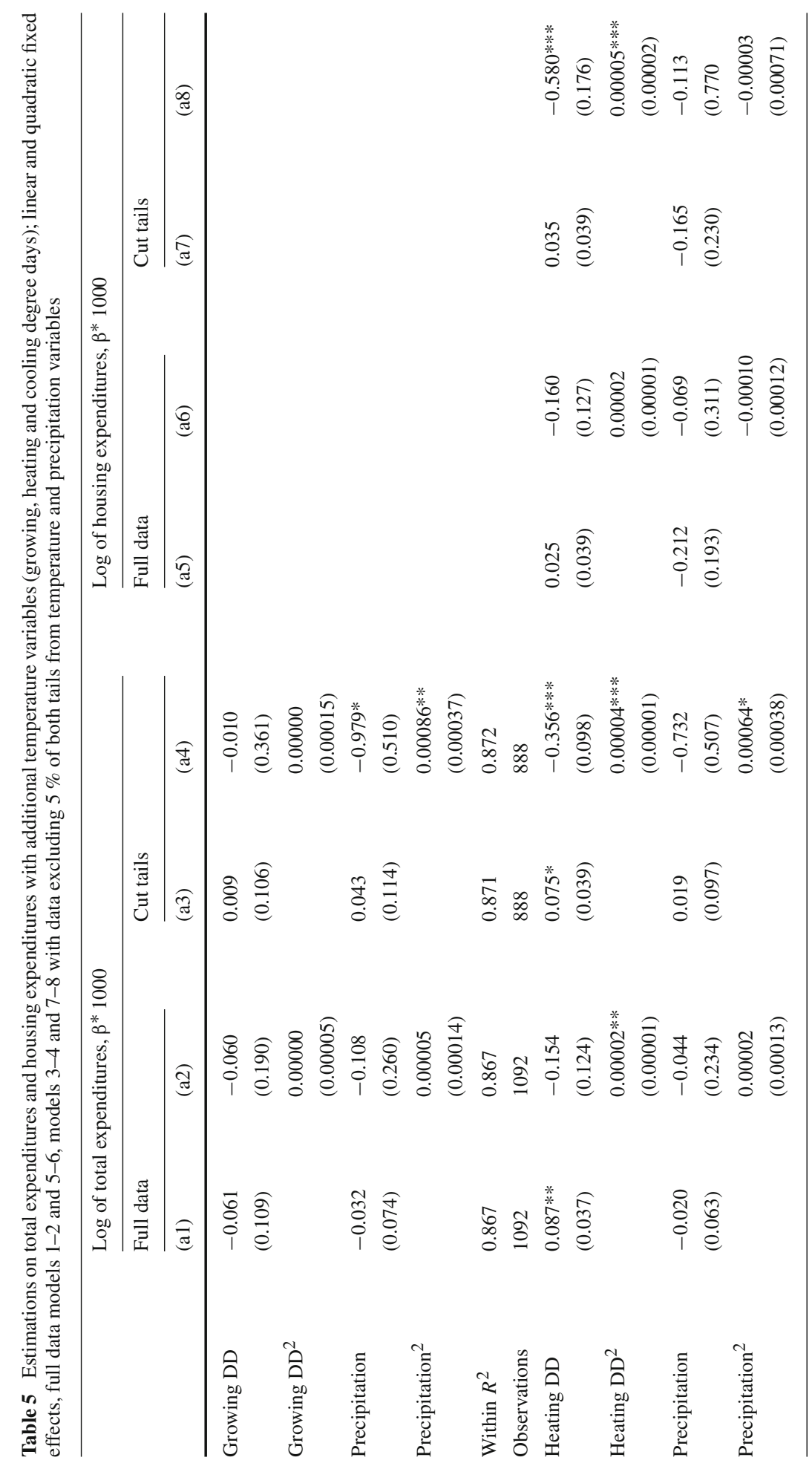




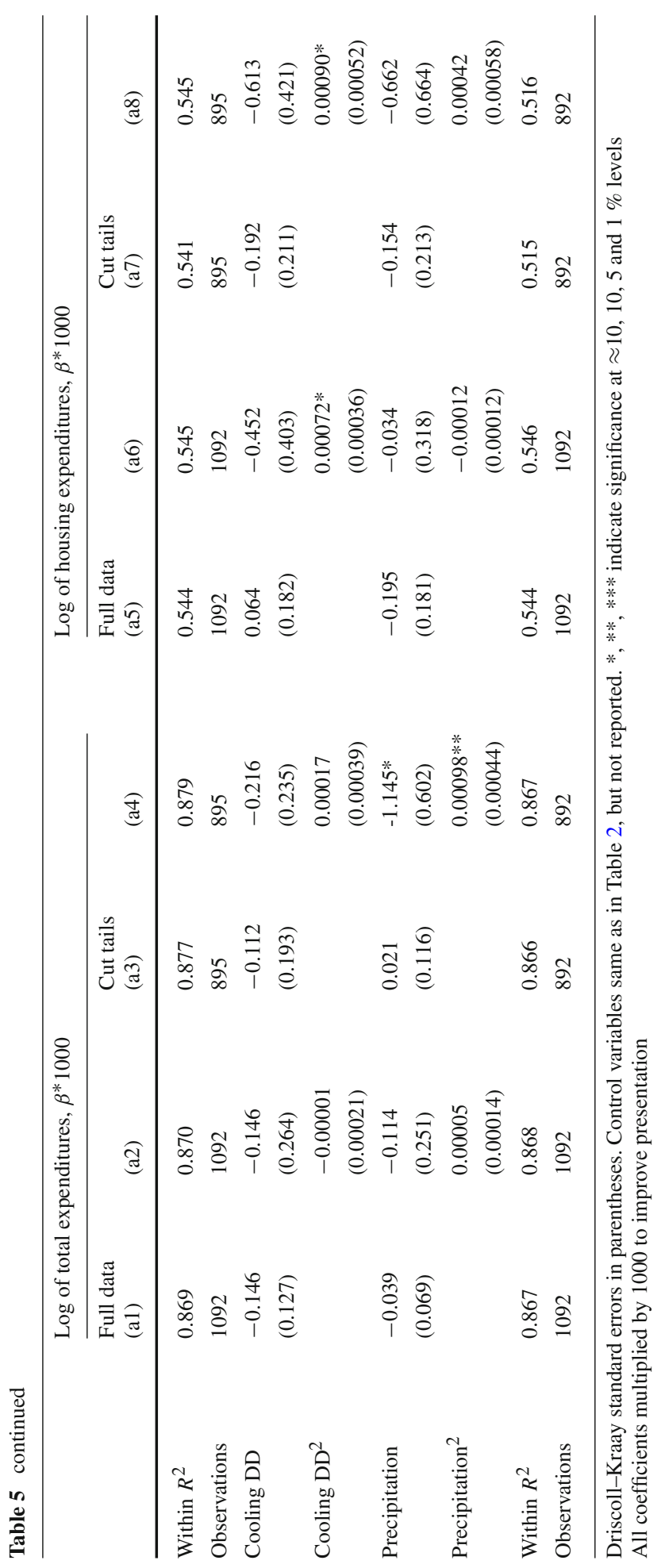


Table 6 Long-difference (LD) estimations with additional temperature variables, full data and data excluding $5 \%$ of both tails from temperature and precipitation variables

Control variables as in Table 3, but not reported. Normal robust standard errors in the parentheses

Table 7 Fixed effects estimations using mid-term climate with full data and data excluding $5 \%$ of both tails from temperature and precipitation variables

Robust standard errors in parentheses. Time dummy included but not reported

\begin{tabular}{|c|c|c|c|c|}
\hline & \multicolumn{2}{|c|}{ Total expenditures } & \multicolumn{2}{|c|}{ Housing expenditures } \\
\hline & Full data & Cut tails & Full data & Cut tails \\
\hline \multirow[t]{2}{*}{ Growing DD } & -0.0009 & -0.0007 & & \\
\hline & $(0.0006)$ & $(0.0006)$ & & \\
\hline \multirow[t]{2}{*}{ Precipitation } & -0.0005 & 0.0000 & & \\
\hline & $(0.0008)$ & $(0.0007)$ & & \\
\hline$R^{2}$ & 0.22 & 0.28 & & \\
\hline Observations & 78 & 71 & & \\
\hline \multirow[t]{2}{*}{ Heating DD } & $0.0009 * * *$ & $0.0010 * * *$ & $0.0008^{*}$ & $0.0011^{* *}$ \\
\hline & $(0.0003)$ & $(0.0003)$ & $(0.0005)$ & $(0.0005)$ \\
\hline \multirow[t]{2}{*}{ Precipitation } & -0.0004 & -0.0005 & $-0.0020^{*}$ & -0.0017 \\
\hline & $(0.0007)$ & $(0.0008)$ & $(0.0012)$ & $(0.0014)$ \\
\hline$R^{2}$ & 0.30 & 0.25 & 0.20 & 0.25 \\
\hline Observations & 78 & 70 & 78 & 70 \\
\hline \multirow[t]{2}{*}{ Cooling DD } & -0.0014 & -0.0013 & 0.0004 & 0.0006 \\
\hline & $(0.0011)$ & $(0.0011)$ & $(0.0019)$ & $(0.0018)$ \\
\hline \multirow[t]{2}{*}{ Precipitation } & -0.0006 & -0.0007 & -0.0019 & -0.0018 \\
\hline & $(0.0008)$ & $(0.0009)$ & $(0.0013)$ & $(0.0014)$ \\
\hline$R^{2}$ & 0.22 & 0.21 & 0.17 & 0.16 \\
\hline Observations & 78 & 70 & 78 & 70 \\
\hline
\end{tabular}

\begin{tabular}{|c|c|c|c|c|}
\hline & \multicolumn{2}{|c|}{ Total expenditures } & \multicolumn{2}{|c|}{ Housing expenditures } \\
\hline & Full data & Cut tails & Full data & Cut tails \\
\hline Temperature & $\begin{array}{l}-0.342 * * * \\
(0.119)\end{array}$ & $\begin{array}{l}-0.321 * * \\
(0.137)\end{array}$ & $\begin{array}{l}-0.228 \\
(0.178)\end{array}$ & $\begin{array}{l}-0.216 \\
(0.193)\end{array}$ \\
\hline Precipitation & $\begin{array}{l}-0.001 \\
(0.001)\end{array}$ & $\begin{array}{l}-0.001 \\
(0.001)\end{array}$ & $\begin{array}{l}-0.002 * \\
(0.001)\end{array}$ & $\begin{array}{l}-0.003 * * \\
(0.001)\end{array}$ \\
\hline Pop. density & $\begin{array}{l}-0.051 \\
(0.037)\end{array}$ & $\begin{array}{l}-0.046 \\
(0.041)\end{array}$ & $\begin{array}{l}0.227 * * * \\
(0.079)\end{array}$ & $\begin{array}{l}0.197 * * \\
(0.087)\end{array}$ \\
\hline Overage & $\begin{array}{l}0.265 \\
(0.903)\end{array}$ & $\begin{array}{l}0.517 \\
(0.973)\end{array}$ & $\begin{array}{l}2.385^{*} \\
(1.315)\end{array}$ & $\begin{array}{l}2.509 * \\
(1.398)\end{array}$ \\
\hline Underage & $\begin{array}{l}2.007 \\
(1.332)\end{array}$ & $\begin{array}{l}2.033 \\
(1.347)\end{array}$ & $\begin{array}{l}3.774 * * \\
(1.676)\end{array}$ & $\begin{array}{l}3.368 * * \\
(1.662)\end{array}$ \\
\hline Communist & $\begin{array}{l}0.323 \\
(0.441)\end{array}$ & $\begin{array}{l}0.442 \\
(0.637)\end{array}$ & $\begin{array}{l}-1.374 \\
(0.888)\end{array}$ & $\begin{array}{l}-0.383 \\
(1.227)\end{array}$ \\
\hline Industrial growth & $\begin{array}{l}0.017 * * * \\
(0.003)\end{array}$ & $\begin{array}{l}0.018 * * * \\
(0.004)\end{array}$ & $\begin{array}{l}0.010 \\
(0.008)\end{array}$ & $\begin{array}{l}0.015 * * \\
(0.007)\end{array}$ \\
\hline Public housing & & & $\begin{array}{l}0.004 \\
(0.007)\end{array}$ & $\begin{array}{l}0.006 \\
(0.008)\end{array}$ \\
\hline Within- $R^{2}$ & 0.93 & 0.92 & 0.20 & 0.21 \\
\hline Observations & 156 & 136 & 156 & 136 \\
\hline
\end{tabular}




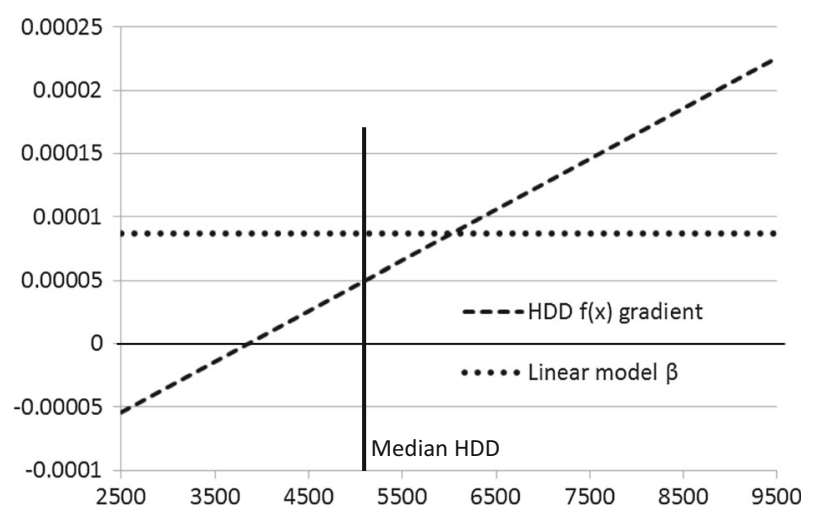

Fig. 4 Graphical result of the heating degree days estimations (a1) and (a2), x-axis is HDD, y-axis is the HDD effect at different HDD $\left(100^{*} \beta=\%\right)$

\section{References}

Angrist JD, Pischke J-S (2009) Mostly harmless econometrics: an empiricist's companion, 1st edn, vol 1, no 8769. Economics Books, Princeton University Press, Princeton

Berkeley Earth (2014) Open online database for global climate data at http://berkeleyearth.org/ (data retrieved in 2014)

Borensztein E, Cavallo E, Valenzuela P (2008) Debt sustainability under catastrophic risk: the case for Government Budget Insurance. IMF working paper WP/08/44

Bräuer I, Umpfenbach K, Blobel D, Grünig M, Best A, Peter M, Lückge H (2009) Klimawandel: Welche Belastungen entstehen für die Tragfähigkeit der Öffentlichen Finanzen? Ecologic Institut

Burke M, Emerick K (2013) Adaptation to climate change: evidence from US agriculture. University of California, Berkeley

Central Election Commission of the Russian Federation. http://www.izbirkom.ru/region/izbirkom

CRU-A. New M, Hulme M, Jones PD (1999) Representing twentieth century space-time climate variability. Part 1: development of a 1961-90 mean monthly terrestrial climatology. J Clim 12:829-856

CRU-B. New M, Hulme M, Jones PD (2000) Representing twentieth century space-time climate variability. Part 2: development of 1901-96 monthly grids of terrestrial surface climate. J Clim 13:2217-2238

CRU-C. New M, Lister D, Hulme M, Makin I (2002) A high-resolution data set of surface climate over global land areas. Clim Res 21:1-25

CRU-D. Mitchell TD, Jones PD (2005) An improved method of constructing a database of monthly climate observations and associated high-resolution grids. Int J Clim 25:693-712

De Silva MO, Kurlyandskaya G, Andreeva E, Golovanova N (2009) Intergovernmental reforms in the Russian federation: one step forward, two steps back? World Bank, Washington, DC. https://openknowledge. worldbank.org/handle/10986/2668

Desai RM, Freinkman LM, Goldberg I (2003) Fiscal federalism and regional economic growth: evidence from the Russian Federation in the 1990s. Policy Research Working Paper 3138, World Bank, Washington, DC, Sept 2003

Deschênes O, Greenstone M (2007) The economic impacts of climate change: evidence from agricultural output and random fluctuations in weather. Am Econ Rev 97(1):354-385

Deschênes O, Greenstone M (2011) Climate change, mortality, and adaptation: evidence from annual fluctuations in weather in the US. Am Econ J Appl Econ 3(October 2011):152-185

Dell M, Jones BF, Olken BA (2014) What do we learn from the weather? The new climate-economy literature. J Econ Lit 52(3):740-798

Dell M, Jones BF, Olken BA (2012) Temperature shocks and economic growth: evidence from the last half century. Am Econ J Macroecon 2012 4(3):66-95

Driscoll JC, Kraay AC (1998) Consistent covariance matrix estimation with spatially dependent panel data. Rev Econ Stat 80:549-560

Durevall D, Henrekson M (2011) The futile quest for a grand explanation of long-run government expenditure. J Public Econ 95(7-8):708-722 
EPA-United States Environmental Protection Agency (2014) Climate change indicators in the United States: heating and cooling degree days. http://www.epa.gov/climatechange/pdfs/print_heating-cooling-2014. pdf

GAIN—Global Adaptation Institute (2012) http://index.gain.org

Guiteras R (2009) The impact of climate change on Indian agriculture. University of Maryland, Mimeo

Heipertz M, Nickel C (2008) Climate change brings stormy days: case studies on the impact of extreme weather events on public finances. doi:10.2139/ssrn.1997256

Hoechle D (2007) Robust standard errors for panel regressions with cross-sectional dependence. Stata J $7(3): 281-312$

IPCC (2007) Climate change 2007: impacts, adaptation and vulnerability. Contribution of working group II to the fourth assessment report of the intergovernmental panel on climate change

IPCC (2014) The fifth assessment report. International Panel of Climate Change. http://www.ipcc.ch/report/ ar $5 /$ syr/

Jones B, Keen M, Strand J (2012) Fiscal implications of climate change. World Bank Policy Research working paper 5956

Korppoo A (2008) Russia and the post-2012 climate regime: foreign rather than environmental policy. The Finnish Institute of International Affairs Briefing Paper 23

Kotlyakov V (2002) Russia's climate-description. Land resources of Russia + CD-ROM. Int Inst Appl Syst Anal Investig 45(1):193-216

Kurlianskaya G (2013) Russian federation: development of public finances and subnational debt markets. In: Canuto O, Liu L (eds) Until debt do us part: subnational debt, insolvency, and markets. The Worldbank, Washington, DC. doi:10.1596/9780821397664_CH12

Lioubimtseva E (2010) Russia's role in the post-2012 climate change policy: key contradictions and uncertainties. Forum on Public Policy: Online Journal of the Oxford Round Table, 10(3), September 2010

Lis EM, Nickel C (2009) The impact of extreme weather events on budget balances and implications for fiscal policy. European Central Bank Working Paper Series 1055, May 2009

Melecky M, Raddatz C (2011) How do governments respond after catastrophes? Natural-disaster shocks and the fiscal stance. World Bank Policy Research Working Paper 5564

Merrifield J (2000) State government expenditure determinants and tax revenue determinants revisited. Public Choice 102(1-2):25-48

Mendelsohn R, Nordhaus WD, Shaw D (1994) The impact of global warming on agriculture: a Ricardian analysis. Am Econ Rev 84(4):753-771

Noy I, Nualsri A (2011) Fiscal storms: public spending and revenues in the aftermath of natural disasters. Environ Dev Econ 16(01):113-128

Osberghaus D, Reif C (2010) Total costs and budgetary effects of adaptation to climate change: an assessment for the European Union. ZEW discussion paper no. 10-046

Ouattara B, Strobl E (2013) The fiscal implications of hurricane strikes in the Caribbean. Ecol Econ 85:105-115

Pynnönniemi K (2012) Russian critical infrastructures-vulnerabilities and policies (editor). FIIA Report 35, The Finnish Institute of International Affairs

Roshydromet (2014) Second assessment report on climate change and its consequences in Russian Federation-General summary. Moscow- 2014

Roshydromet (2008) Assessment report on climate change and its consequences in Russian Federationgeneral summary. Moscow-2008

Rosstat-Regioni Rossii database, various issues

Sanz I, Velázques FJ (2002) Determinants of the composition of government expenditure by functions. European Economy Group Working Paper No. 13/2002

Schlenker W, Roberts MJ (2009) Nonlinear temperature effects indicate severe damages to US crop yields under climate change. PNAS 106(37):15594-15598

Schuknecht L (1999) Fiscal policy cycles and the exchange rate regime in developing countries. Eur J Polit Econ 15:569-580

Schultz A, Libman A (2015) Is there a local knowledge advantage in federations? Evidence from a natural experiment. Public Choice 162:25-42

Seo SN (2013) An essay on the impact of climate change on US agriculture: weather fluctuations, climatic shifts, and adaptation strategies. Clim Change 121(2):115-124

Shelton CA (2007) The size and composition of government expenditure. J Public Econ 91(2007):2230-2260

Slinko I, Yakovlev E, Zhuravskaya E (2005) Laws for sale: evidence from Russia. Am Law Econ Rev 7(1):284318

Solanko L (2006) Coping with missing public infrastructure: an analysis of Russian industrial enterprises. In: Solanko L (ed) Essays on Russia's economic transition. Scientific monographs E:26, Bank of Finland 
Solanko L, Tekoniemi M (2005) To recentralize or decentralize—some recent trends in Russian fiscal federalism. BOFIT Online 5/2005, BOFIT, Helsinki

Tol RSJ (2005) Adaptation and mitigation: trade-offs in substance and method. Environ Sci Policy 8:572-578

Turkowski A (2012) Russia's international climate policy. The Polish Institute of International Affairs Policy Papers No. 27

World Bank (2010) The cost to developing countries of adapting to climate change: new methods and estimates. Consultation draft. World Bank, Washington

World Bank (2011) Social expenditure and fiscal federalism in Russia. Public Expenditure Review (PER). World Bank, Washington, Jan 2011

Zhuravskaya E (2010) Federalism in Russia. In: Åslund Anders, Guriev Sergei, Kuchins Andrew (eds) Russia after the global economic crisis. PIIE, Washington 